\title{
An Amyloid Agnostic Reformulation of the Alzheimer's Disease: the Long Gene Vulnerability Hypothesis
}

\author{
Sourena Soheili-Nezhad ${ }^{1}$ \\ ${ }^{1}$ Donders Institute for Brain, Cognition and Behaviour, Radboud University Medical Centre, \\ Nijmegen, the Netherlands \\ email: sourena.soheili-nezhad@,donders.ru.nl
}




\section{Abstract}

Alzheimer's disease (AD) is a genetically complex senile neurodegeneration with unknown etiology. The first gene discovered to be mutated in early-onset $\mathrm{AD}$, the amyloid precursor protein (APP), has been widely assumed as a causal factor in the disease cascade due to its generation of $\mathrm{A} \beta$ species. APP has an evolutionarily conserved biological role and activates a signaling program with notable similarities to integrin - a cell adhesion receptor with a wide array of functions. Intriguingly, several AD genome-wide association study (GWAS) candidate genes, including the SHARPIN locus recently reported by us and others, influence signaling of the integrin pathway. Integrins are focal adhesion regulators and serve in nervous system development, synaptic plasticity, and Tau phosphorylation. These observations suggest that the function of APP probably goes beyond $\mathrm{A} \beta$ generation in $\mathrm{AD}$.

Aging - the strongest risk factor for AD — is associated with various clock-like events in cells. For instance, neurons are continuously impacted by stochastic 'hits' to their genomes in aging, in the forms of DNA damage, insertion-deletions, copy-number variations (CNVs) and other types of somatic mutations. DNA damage and somatic mutations can result in neoplastic changes and cancer in mitotically active cells. However, their consequences in post-mitotic cells such as aging neurons are less defined.

The current hypothesis holds that the stochastic loss of DNA sequence data at random loci in aging affects longer genes by chance more frequently. As a result, the biological processes coordinated by long genes may be more vulnerable to such random aging effects. Curiously, as shown by us and others, long genes are strongly enriched for synapse- and cell adhesion-related ontologies, more than any other biological process or cellular compartment. In addition, among various cell types, neurons possess the highest levels of long gene expression and are therefore more vulnerable to such harmful effects. The long gene vulnerability hypothesis provides a simple link between aging and the genetic landscape of $\mathrm{AD}$ and warrants new strategies for disease modification.

Keywords: Alzheimer's disease, DNA damage, somatic mutation, integrin, synaptic adhesion 


\section{Introduction}

The A $\beta$ fragment of the APP protein ${ }^{1}$ has been the centerpiece of AD pathogenesis research and drug design following the amyloid cascade theory ${ }^{2}$. However, more than three decades after the successful cloning of the APP gene ${ }^{3}$, the biological function of its encoded protein remains speculative in the brain and elsewhere. Mounting evidence indicates that APP acts as a cell surface receptor and activates an intracellular signaling program ${ }^{4,5}$ for synaptic function and plasticity $^{6}$. Still, this essential biological function has received less attention in the field.

Sporadic late-onset $\mathrm{AD}$ is a genetically complex disease with a heritability of $60-80 \%{ }^{7}$. GWAS and next-generation sequencing have identified multiple risk loci for late-onset AD in the last decade ${ }^{8-11}$. These loci provide a hypothesis-free glimpse of the underlying molecular pathways in AD and bring opportunities for revising disease models in a data-driven way. APP, presenilins (PSENs), and Tau variants have shown small contributions to the total heritability of late-onset $\mathrm{AD}^{10,12}$, whereas the APOE locus explains approximately a quarter of the disease heritability ${ }^{13}$. The GWAS loci have been suggested to highlight several pathways in AD pathogenesis, spanning microglial activation, lipid metabolism, focal adhesion, and $\mathrm{A} \beta$ turnover ${ }^{14-17}$. Nevertheless, the causal significance of $A \beta$ in AD is a matter of ongoing debate ${ }^{18-}$ 20. The correlation between $A \beta$ and brain atrophy seems to be weak, absent, and in recent reports paradoxically negative ${ }^{21}$.

It is argued here that the model of AD pathogenesis can be surprisingly simplified by reimagining $A \beta$ deposition and Tau phosphorylation as potential consequences of the disease process rather than causal factors. Several testable predictions are proposed together with new disease modification strategies.

\section{APP may be a synaptic adhesion molecule: the evolutionarily-conserved NPxY motif}

Three APP family genes are present in the human genome, including APP, APLP1, and APLP2. The common function of this gene family, biological adhesion ${ }^{22}$, has been highly conserved in evolution. As a receptor-like protein, transmembrane APP transfers extracellular signals to the internal actin cytoskeleton and affects focal adhesion stability ${ }^{4,23}$. Specifically, APP interacts with many extracellular molecules that are classical ligands for integrins, such as heparan sulfate, laminin, and fibronectin ${ }^{24-27}$. Similar to the integrin pathway, APP moderates neuronal growth cone adhesion and movement ${ }^{28,29}$. For example, the APP protein directly interacts with $\beta 1$ integrin at cell membranes and influences focal adhesion ${ }^{30,31}$, cell motility ${ }^{32}$, and hippocampal neurite outgrowth ${ }^{33,34}$. In addition to direct interaction with integrin, APP also binds to two extracellular adhesion molecules that act as integrin-activating ligands ${ }^{34,35}$, including reelin ${ }^{34}$ and netrin ${ }^{36,37}$. This biological convergence with integrin suggests that APP may take part in the integrin adhesion complex and modulate its downstream signaling effects on the cytoskeleton. 
The intracellular domain of APP attracts adaptor molecules with signaling activity ${ }^{38-40}$. Specifically, the APP intracellular domain constitutes an NPxY amino acid motif that has been super-conserved from roundworms to humans for more than 900 million years of evolution ${ }^{41}$. NPxY is a consensus motif for receptor sorting and intracellular signaling. For instance, integrins recruit their cytoplasmic adaptors (e.g., kindlin and talin) via a cytoplasmic NPXY motif, and this event ultimately affects the remodeling of the actin cytoskeleton ${ }^{42}$. Similarly, the NPxY-binding APP intracellular adaptors converge to the same cytoskeletal actin pathway ${ }^{4,23}$ (table 1). Notably, APOE lipoprotein receptors also recruit the same NPxY motif for signaling (as shall be discussed in the next sections).

Several lines of evidence suggest that APP may be a synaptic protein. At the postsynapse, APP interacts with AIDA1, a synaptic plasticity regulator, via its NPxY site ${ }^{43,44}$. The APP family proteins form trans-synaptic adhesion dimers, stabilize synaptic connections ${ }^{45}$ and coordinate neurotransmitter receptor function ${ }^{46,47}$. Taken together, the signaling function of $\mathrm{APP}^{6}$ seems to overlap with that of integrin cell adhesion and its influence on synaptic plasticity ${ }^{48,49}$. This amyloid-independent role of APP dovetails with the body of GWAS evidence and the genetic architecture of $\mathrm{AD}$.

Table 1. Extracellular and intracellular APP binding molecules

\begin{tabular}{|c|c|c|c|}
\hline & Binding site & Function & Integrin modulation \\
\hline FE65/TIP60 & AICD & Cell adhesion and migration, cytoskeletal remodeling 50,51 & $\beta 1$ integrin $^{52}$ \\
\hline KAl1 & $\mathrm{AICD}$ & Cell migration, cytoskeletal assembly ${ }^{53,54}$ & $\beta 1$ integrin 55 \\
\hline DISC1 & AICD & Neuronal migration and cytoskeletal remodeling ${ }^{56,57}$ & $\beta 1$ integrin 58 \\
\hline DAB1 & $\mathrm{AICD}$ & Neuronal migration and cytoskeletal remodeling 59 & $\beta 1$ integrin $^{60}$ \\
\hline MINT1 & $\mathrm{AICD}$ & Cell migration 61 & Unknown \\
\hline GRB2 & $\mathrm{AICD}$ & Cell migration 62,63 & $\beta 1$ integrin 62 \\
\hline $\mathrm{SHC}$ & $\mathrm{AICD}$ & Cell adhesion and migration 63,64 & $\beta 1$ integrin 65 \\
\hline GRB7 & $\mathrm{AICD}$ & Cell adhesion and migration ${ }^{66}$ & (ß1-)integrin67 \\
\hline CRK & $\mathrm{AICD}$ & Cell migration and cytoskeletal remodeling68 & $\beta 1$ integrin $^{69}$ \\
\hline PIN1 & $\mathrm{AICD}$ & Cell migration ${ }^{70}$ & $\beta 1$ integrin $^{71}$ \\
\hline Lingo1 & Extracellular & Cell migration 72,73 & $\beta 1$ integrin $^{74}$ \\
\hline Pancortin & Extracellular & Cell migration ${ }^{75}$ & Unknown \\
\hline Reelin & Extracellular & Cell migration ${ }^{76}$ & $\beta 1$ integrin $^{76}$ \\
\hline Netrin1 & Extracellular & Cell migration and synaptic actin remodeling 77,78 & $\beta 1$ integrin $^{79}$ \\
\hline F-spondin & Extracellular & Cell adhesion and migration 80,81 & $\beta 3$ integrin 82 \\
\hline
\end{tabular}

AICD: APP intracellular domain

\section{$\Gamma$-secretase may be a synaptic adhesion modulator}

Although $\gamma$-secretase dysfunction has been primarily researched in the context of A $\beta$ generation, the function of this transmembrane protease is not limited to APP cleavage ${ }^{83}$. Several receptors such as notch ${ }^{84}$, which is a novel familial AD candidate gene ${ }^{85}$, rely on $\gamma$-cleavage for normal signaling. Other $\gamma$-secretase substrates associated with AD include the APOE lipoprotein receptors $\left(\operatorname{LRPs}^{86}\right)$ and the ephrin synaptic adhesion receptors ${ }^{87}$, both of which regulate 
neurotransmission ${ }^{86,88}$ and interact with the integrin adhesion complex ${ }^{89,90}$. Synaptic maturation is accompanied by an increased expression of $\gamma$-secretase at the postsynaptic membranes ${ }^{91}$, where this enzyme is anchored to various cell adhesion molecules ${ }^{91-93}$. Loss of $\gamma$-secretase activity disrupts membrane adhesion force generation ${ }^{94}$ and causes erroneous axonal pathfinding ${ }^{95}$. Taken together, $\gamma$-secretase is essential to the signaling of multiple synaptic adhesion receptors other than APP, a physiological cleavage process that has been hardly explored in $\mathrm{AD}$ pathogenesis.

\section{The genome-wide landscape of $A D$ and synaptic adhesion}

Pioneered by Lambert et al., multiple GWAS risk loci have been discovered for late-onset $\mathrm{AD}$ in the last decade ${ }^{12,96}$. Curiously, GWAS candidate genes seem to strongly converge to the integrin cell adhesion pathway - a mechano-chemical signaling event that transfers extracellular matrix (ECM) signals to the internal actin cytoskeleton and vice versa. Integrins are heterodimeric receptors generated from $18 \alpha$ and eight $\beta$ subunits in humans. These cell adhesion receptors coordinate bidirectional communications between the cell and the ECM, for instance, in synapse development and plasticity modulation ${ }^{48}$. Many of the GWAS loci code for proteins that interact with the $\beta 1$ integrin pathway, such as the Src family kinases (SFKs), focal adhesion kinase (FAK), and actin reorganizers (table 2 and Fig. 1). Notably, the integrin pathway prevents Tau phosphorylation via integrin-linked kinase (ILK). In this context, tau phosphorylation and ILK change the plasticity of cytoskeletal actin in neurites, an essential process for synaptic reshaping and outgrowth ${ }^{97-101}$.

The endocytosis machinery has been implicated by multiple risk loci of AD, including BIN1, PICALM ${ }^{102}$ and ABCA $7{ }^{103}$. Endocytosis via clathrin ${ }^{104}$ and IDOL-dependent pathways ${ }^{105}$ regulates synaptic biology. Synaptic endocytosis modulates the strength of transmission by redistributing the pool of transmitter receptors from the postsynaptic density membrane (active state) to the intrasynaptic space (inactive state). For instance, LRPs are endocytic receptors of the APOE molecule and modulate postsynaptic glutamate receptor trafficking and plasticity ${ }^{106,107}$. Both LRPs and integrins recruit the clathrin-mediated endocytosis machinery via their NPXY motifs ${ }^{108}$. Intriguingly, kindlin-2, a known AD risk locus, links the LRP-mediated endocytosis to the integrin cell adhesion pathway ${ }^{109}$. 
Table 2. AD risk genes and their implication of the integrin cell adhesion pathway

\begin{tabular}{|c|c|c|c|}
\hline & Cell adhesion function & $\begin{array}{l}\text { Interaction with integrin and focal } \\
\text { adhesion }\end{array}$ & $\begin{array}{l}\text { Actin cytoskeleton } \\
\text { reorganization }\end{array}$ \\
\hline EPHA1 & Cancer cell invasion ${ }^{110}$ & $\beta 1$ integrin 111,112 & RhoA, ROCK pathway ${ }^{112}$ \\
\hline FRMD4A & Cell adhesion and invasion ${ }^{113}$ & FAK $^{114,115}$ & Arf6 116 \\
\hline FERMT2 & Cell invasion ${ }^{117}$ & FAK $^{114,115}$ & Unknown \\
\hline GAB2 & Cell adhesion and migration ${ }^{118}$ & $\beta 1$ integrin 118 & Rho pathway ${ }^{119}$ \\
\hline CASS4 & Axon guidance ${ }^{120}$, cell migration ${ }^{121}$ & Integrin 120 and FAK 121 & Rho, Rac1, Rap1 pathway ${ }^{122}$ \\
\hline CD2AP & Podocyte focal adhesion 123 & $\alpha 3$ integrin 123 & Direct actin binding ${ }^{124}$ \\
\hline PTK2B & Cell migration 125 & FAK, SRC ${ }^{126}$ & Actin reorganization ${ }^{126}$ \\
\hline INPP5D & Cell movement ${ }^{127}$ & $\beta 3$ integrin ${ }^{127,128}$ & $\begin{array}{l}\text { TREM2-mediated cytoskeletal } \\
\text { rearrangement }\end{array}$ \\
\hline NYAP1 & Neuronal migration ${ }^{130}$ & $\mathrm{Fyn}^{130}$ & PI3K/WAVE1 pathway ${ }^{131}$ \\
\hline BIN1 & $\begin{array}{l}\text { Clathrin-mediated endocytosis, focal } \\
\text { adhesion }{ }^{132} \text {. AMPH ( } 71 \% \text { sequence } \\
\text { similarity) affects hippocampal neurite } \\
\text { outgrowth } 133\end{array}$ & $\beta 1$ integrin ${ }^{132}, \alpha$-integrin ${ }^{134}$, FAK $^{135}$ & Tau-mediated actin dynamics ${ }^{136}$ \\
\hline PICALM & $\begin{array}{l}\text { Unknown; Clathrin-mediated } \\
\text { endocytosis } 137,138\end{array}$ & $\begin{array}{l}\text { Unknown, } \beta 1 \text { integrin endocytosis } \\
\text { through clathrin?139,140 }\end{array}$ & $\begin{array}{l}\text { Genetic interaction with the } \\
\text { actin regulator DOCK1 } 141\end{array}$ \\
\hline ABCA7 & $\begin{array}{l}\text { Unknown; Clathrin-mediated } \\
\text { endocytosis }{ }^{142}\end{array}$ & Unknown & Unknown \\
\hline UNC5C & Axon repulsion 143 & $\alpha 6$ integrin 144 & Unknown \\
\hline TPBG & Cell adhesion and movement ${ }^{145-147}$ & Focal adhesion 148 & Rho pathway148 \\
\hline HBEGF & integrin-dependent cell adhesion 149 & $\alpha 5 \beta 1$ Integrin ${ }^{149}$, FAK $^{150}$ & ErbB-1 150 \\
\hline USP6NL & Cell migration ${ }^{151}$ & $\beta 1$ integrin endocytosis ${ }^{151}$ & Rab5151 \\
\hline TREM2 & Unknown & $\beta 1$ and $\beta 3$ integrin ${ }^{152}$ & $\begin{array}{l}\text { DAP12-mediated cytoskeletal } \\
\text { reorganization } 129\end{array}$ \\
\hline TTC3 & Unknown & $\beta 1$ integrin/FAK 153 & RhoA, ROCK ${ }^{154}$ \\
\hline PLCG2 & Cell migration ${ }^{155}$ & $\beta 1$ and $\beta 2$ integrin, SFK ${ }^{155,156}$ & Unknown \\
\hline $\mathrm{ABI3}$ & Cell migration ${ }^{157}$ & $\begin{array}{l}\text { ABI3 binding protein activates } \beta 1 \\
\text { integrin and } F A K^{158,159}\end{array}$ & WAVE $^{160}$ \\
\hline CLU & Cell adhesion 161 and migration ${ }^{162}$ & Unknown & $\begin{array}{l}\text { LIMK1 }{ }^{161} \text { and PI3K/AKT } \\
\text { pathways }\end{array}$ \\
\hline SHARPIN & Cell adhesion and migration 163,164 & $\beta 1$ integrin 165 & $\begin{array}{l}\text { Postsynaptic actin }{ }^{166}, \text { Rap1, Rho } \\
\text { GTPase }{ }^{164}\end{array}$ \\
\hline ADAM10 & Cell migration ${ }^{167}$ & $\beta 1$ integrin ${ }^{167}$ & Unknown \\
\hline HLA-DRB1 & Cell adhesion and movement ${ }^{168}$ & $\beta 1$ integrin, FAK, Src 169,170 & $\begin{array}{l}\text { Rho GTPase }{ }^{171}, \text { Src, FAK and } \\
\text { Erk }^{170}\end{array}$ \\
\hline NCK2 & Cell adhesion and movement ${ }^{172}$ & Integrin linked kinase ${ }^{173}$ and FAK ${ }^{174}$ & $\begin{array}{l}\text { Cdc42, Rac }{ }^{172}, \text { PINCH and N- } \\
\text { WASP } 175\end{array}$ \\
\hline ACE & Unknown & $\beta 1$ and $\alpha 5$ integrins ${ }^{176}$ & Unknown \\
\hline
\end{tabular}

\section{Long synaptic adhesion genes implicate DNA damage as the cause of AD}

Cell adhesion enlightens new mechanisms of AD pathogenesis. Curiously, among all pathways and cell compartments documented in the gene ontology (GO) database, cell adhesionand synapse-related ontologies show the strongest enrichment of long genes ${ }^{177}$. In addition, gene 
expression data shows that neurons highly express long genes, more than any other cell type ${ }^{178}$. While the reason for this statistical overrepresentation is elusive, it may be speculated that long genes may have increased the complexity of cell signaling pathways in evolution, such as those of brain development and synaptic connectivity. Long genes often possess long introns and more transcription factor binding sites. Also, long genes usually code for larger proteins with larger surface areas and more interaction sites. Elements of the neurodevelopmental program, such as axon guidance, neural migration and synapse formation, may rely on signaling complexities enabled by long gene products. Importantly, these large molecules also contribute to the postdevelopmental plasticity of the synapse ${ }^{179}$.

Several independent groups have recently reported that somatic mutations and insertiondeletions (indels) accumulate in aging brain neurons at a more or less linear rate ${ }^{180-183}$. A long synaptic gene may be more vulnerable to such DNA damage events and somatic mutations (genosenium) that emerge in aging cells. Also, long neuronal genes often reside in chromosomal fragile sites and hot-spots of genome instability ${ }^{184,185}$, a feature that may render them more vulnerable to DNA damage in aging. Loss of long neuronal genes due to DNA damage accumulation may be more or less similar to the mutational loss of long tumor suppressor genes in cancers ${ }^{186}$, albeit with some distinctive features due to the post-mitotic state of neurons.

The biological pathways coordinated by long genes, synapse and cell adhesion, compile the genome-wide landscape of AD with APP, $\gamma$-secretase and APOE. A $\beta$ generation and Tau phosphorylation may be downstream consequences of this causal mechanism (please see the next sections).

\section{Testing the hypothesis: LRP1b, DAB1 and CSMD1 under the spotlight}

The medial temporal lobe neurons express certain synaptic genes such as the NMDA receptor subunits for regulating plasticity and memory formation. NMDA receptors are coupled with synaptic adhesion molecules and cytoskeletal actin (Fig. 1). Due to such proteomic diversity in different brain regions and cells, some neurons may be more vulnerable to aging and DNA damage, for example if they incorporate multiple genes that are mutationally fragile in aging. While an extensive and exploratory search of long and fragile genes in AD may be helpful, three genes have interesting features warranting focused research (table 3):

- LRP1b codes for a receptor of the APOE molecule. LRP1b is the ninth-longest gene in the human genome and is selectively expressed in the hippocampal formation ${ }^{187,188}$ (Fig. 2). This giant receptor maps to the chromosomal fragile site FRA2F and is among the top-ten genes frequently deleted in cancers ${ }^{189}$. Considering its interaction with the postsynaptic density protein PSD95 ${ }^{190}$, the synaptic plasticity regulator PICK ${ }^{191}$, and the APP protein ${ }^{192}$, LRP1b may have postsynaptic roles. The biological functions of its closest homolog, LRP1 (with 59\% sequence similarity), may help speculate potential synaptic roles of LRP1b. LRP1 regulates postsynaptic glutamate receptor trafficking, long-term potentiation ${ }^{193}$ and integrin signaling ${ }^{194}$. Both of these receptors have two NPxY motifs. 
- DAB1 is a mandatory signaling adaptor of the APOE/RELN signaling axis, an essential biological pathway in the perforant synaptic path of the medial temporal lobes ${ }^{195,196}$. DAB1 is coded by the $13^{\text {th }}$ longest gene in the human genome and maps to the chromosomal fragile site FRA1B.

- CSMD1 is another long synaptic gene with tumor-suppressor-like fragility ${ }^{197}$. This gene, which is the sixth-longest gene in the human genome, resides at the chromosomal fragile site FRA8B and prevents activation of the complement system ${ }^{198}$. As a giant synaptic membrane adhesion molecule, CSMD1 is strongly expressed in the hippocampal formation $^{188}$. These features warrant research into the potential loss of CSMD1 in the aging brain and its possible influence on complement activation, synaptic pruning ${ }^{199}$ and integrin signaling ${ }^{200}$. Notably, the $\mathrm{C} 3 \mathrm{~b}-4 \mathrm{~b}$ complement complex - a cognate ligand for the $\mathrm{AD}$ risk locus CR1 receptor-is degraded by $\mathrm{CSMD} 1^{198}$. 


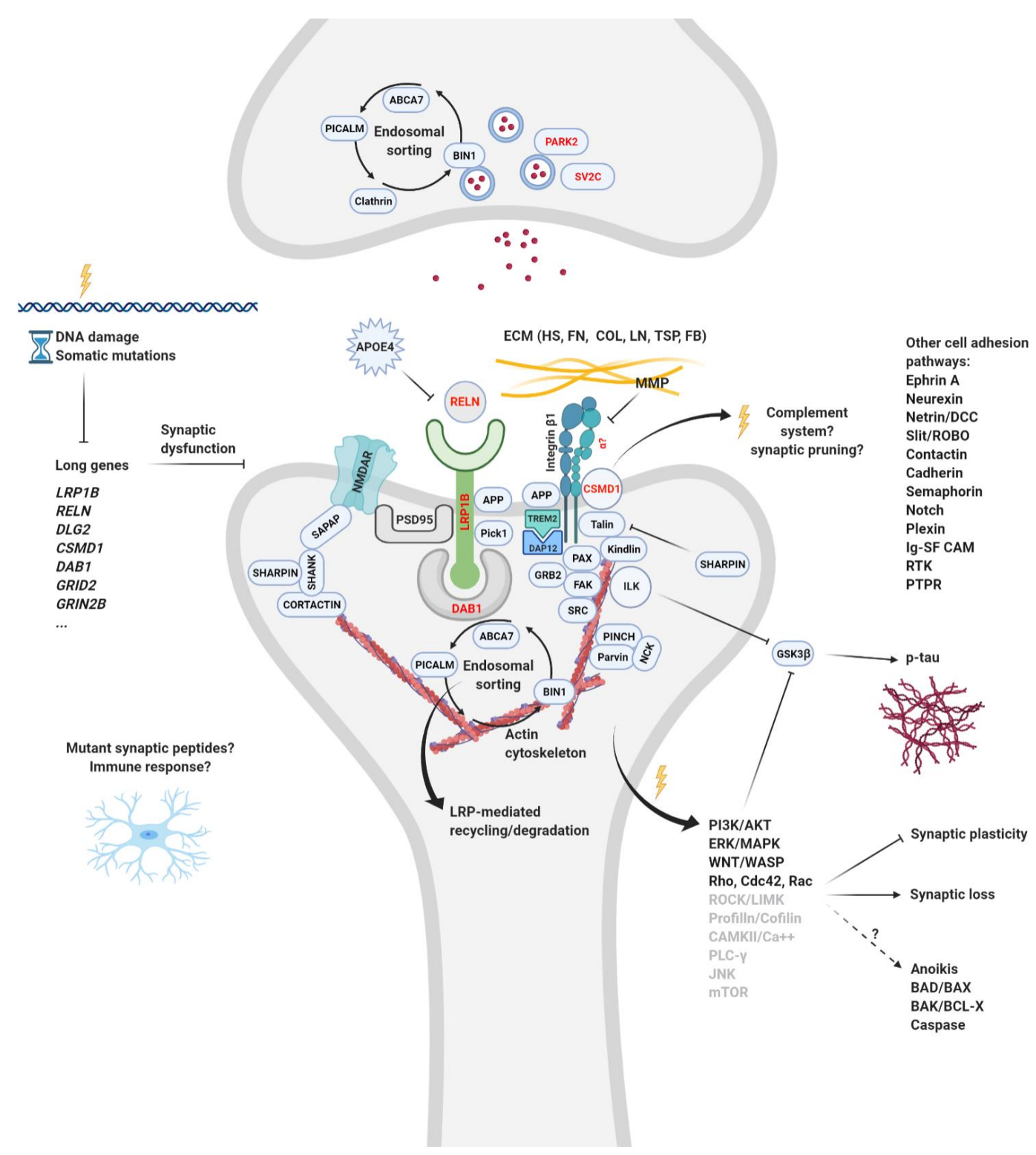

Figure 1. The postsynaptic adhesion pathway. The integrin cell adhesion pathway interacts with several candidate $\mathrm{AD}$ risk gene products. A number of aging-vulnerable neuronal genes in this molecular interactome (red) may be affected by DNA damage in aging, causing other genes to appear as disease risk loci. PAX: paxillin, RELN: reelin, RTK: receptor tyrosine kinase, PTPR: protein tyrosine phosphatase receptor, MMP: matrix metalloproteinase, FN: fibronectin, LN: laminin, TSP: thrombospondin. Ig-SF CAM: immunoglobulin-superfamily cell adhesion molecule. 


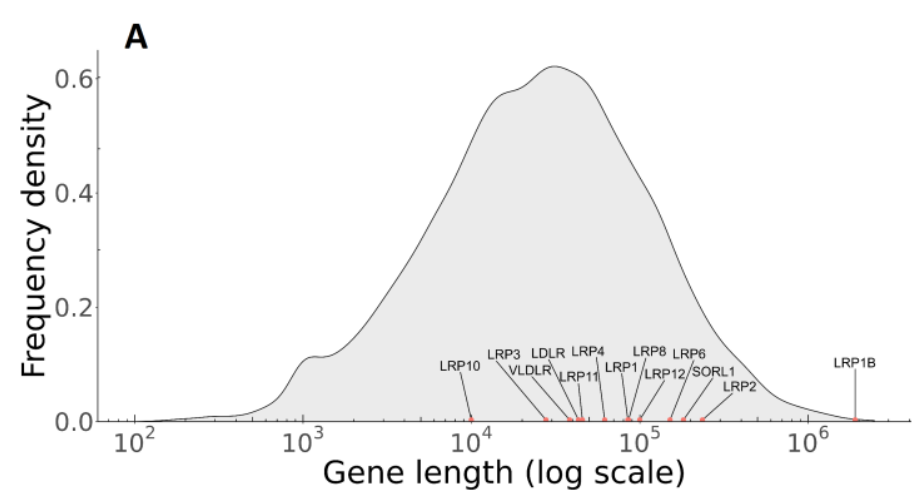

B
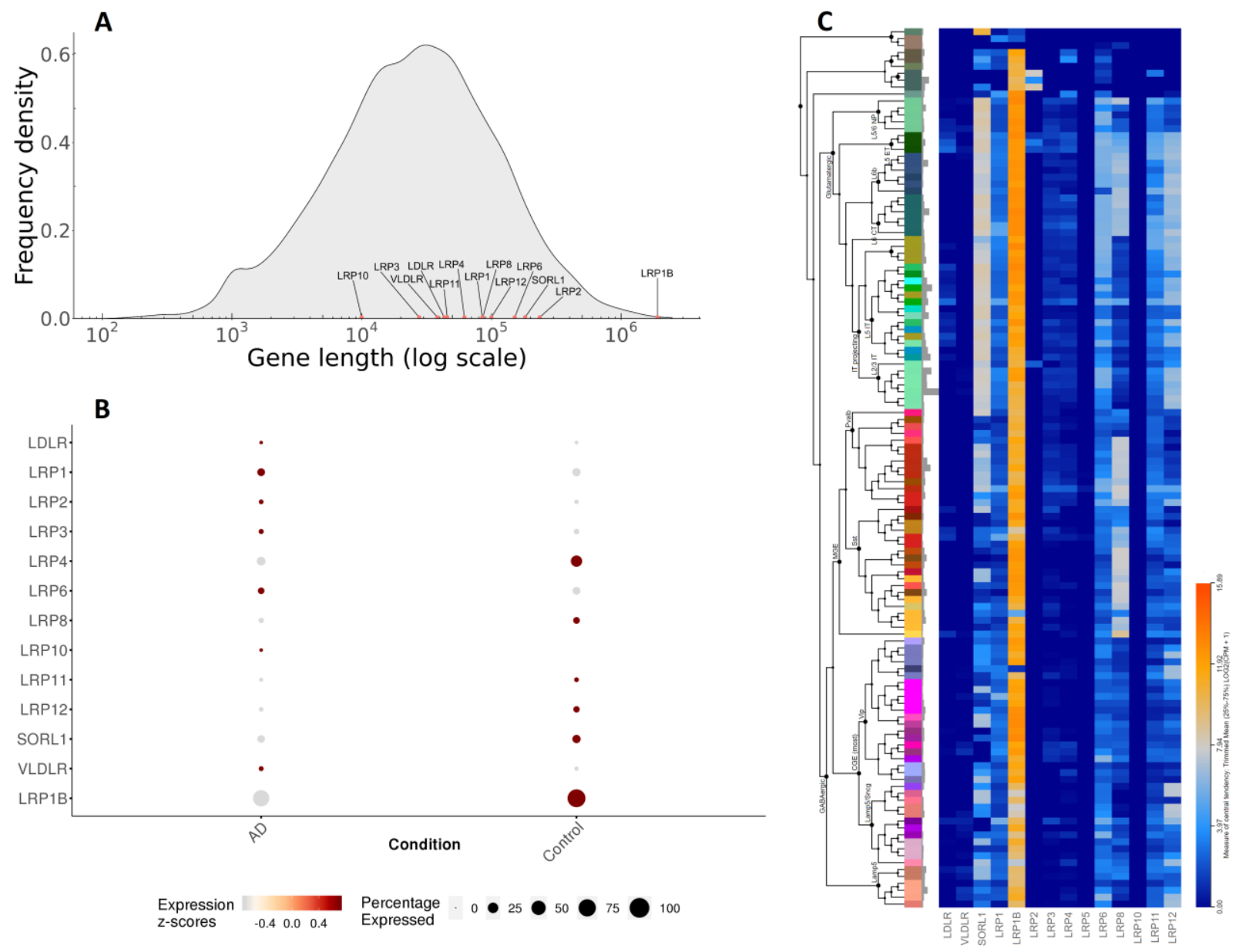

Figure 2. The lipoprotein receptor family. All protein-coding human genes are shown in the frequency density plot $(n=20,006$ genes, Ensembl v99). The lengths of all APOE receptor genes (LRPs) are indicated (A). Expression of LRPs in single entorhinal cortical neurons of non-demented and AD subjects (RNA-seq data; retrieved from http://adsn.ddnetbio.com ${ }^{201}$ ) (B). Single-cell expression of LRPs in subtypes of human cortical neurons (RNA-seq data; retrieved from https://portal.brain-map.org) (C). LRP1b is a positive outlier in all three plots.

\section{Long gene vulnerability and the DNA damage theory of aging}

In the 1950s, Failla and Szilard attributed aging to the 'accumulation of spontaneous somatic mutations in all body cells ${ }^{202}$ ' and the buildup of random events that 'destroy chromosomes ${ }^{203}$. DNA damage has been suspected as a mechanism of neurodegeneration and AD for some time ${ }^{18,204-206}$. Single-cell sequencing has recently revealed an accumulation of somatic mutations in human brain neurons ${ }^{181-183,207,208}$, a process termed genosenium. A number of preliminary works have surveyed somatic mutations in $\mathrm{AD}$ and non-demented brain neurons with inconsistent results ${ }^{183}$. It is noteworthy that the survivorship bias probably confounds single-cell mutational readouts, since different subtypes of neurons show variable degrees of vulnerability to 
AD. As much as $90 \%$ of vulnerable neurons may be lost in severe $\mathrm{AD}^{209}$. In support of this notion, healthy brains seem to lose a substantial proportion of neurons with higher mutational loads in aging ${ }^{210}$. Compared to non-demented brains, AD brains show a reduced number of somatic mutations. While inconclusive, this observation may suggest that neurons with higher mutational loads are generally more vulnerable in the aging brain and are (more) easily depleted in AD. In addition to single nucleotide variant (sSNV), further studies are needed to quantify copy number variations (CNVs) and indels in $\mathrm{AD}$ neurons, since these less-explored types of somatic mutations frequently impair long genes at fragile sites, some of which have neuronal roles $^{211}$. Considering the post-mitotic state of neurons, an interesting question is whether DNA strand break and repair cycles in neurons affect fragile site genes similar to the effect of cell division cycles in cancer pathogenesis ${ }^{212}$.

The current hypothesis brings new elements to the DNA damage theory of aging. Long genes are postulated to be more susceptible to DNA damage and its consequences, such as somatic CNVs and SNVs. This phenomenon is predicted to disable long genes and affect essential synaptic processes, such as the postsynaptic adhesion complex and fragile site genes (table 3 ). 
Table 3. The top 40 longest genes and common fragile sites

\begin{tabular}{|c|c|c|c|c|c|c|}
\hline Rank & Gene & $\begin{array}{l}\text { Transcript } \\
\text { length (bp) }\end{array}$ & $\begin{array}{l}\text { Exon } \\
\text { count }\end{array}$ & $\begin{array}{l}\text { Total exon } \\
\text { length (bp) }\end{array}$ & Fragile site & Disease/pathway \\
\hline 1 & RBFOX1 & $2,471,657$ & 20 & 3,651 & & \\
\hline 2 & CNTNAP2 & $2,304,198$ & 24 & 9,454 & FRA7I & Autism \\
\hline 3 & DLG2 & $2,169,352$ & 28 & 7,959 & FRA11F & Schizophrenia, Parkinson's disease \\
\hline 4 & DMD & $2,092,292$ & 79 & 1,3992 & FRAXC & \\
\hline 5 & PTPRD & $2,084,572$ & 17 & 1,697 & & \\
\hline 6 & CSMD1+ & $2,059,554$ & 70 & 1,4417 & FRA8B & Schizophrenia, cognitive function \\
\hline 7 & MACROD2 & $2,057,829$ & 17 & 4,994 & & \\
\hline 8 & EYS & $1,987,247$ & 43 & 10,590 & & \\
\hline 9 & LRP1B*† & $1,900,279$ & 91 & 15,850 & FRA2F & APOE receptor \\
\hline 10 & CTNNA3 & $1,783,673$ & 18 & 10,696 & FRA10D & \\
\hline 11 & $\mathrm{ROBO} 2$ & $1,740,816$ & 27 & 5,919 & FRA3R & \\
\hline 12 & NRXN3 & $1,691,661$ & 21 & 12,048 & FRA14C & \\
\hline 13 & DAB1* & $1,548,836$ & 15 & 5,301 & FRA1B & APOE/RELN signaling \\
\hline 14 & PDE4D & $1,513,420$ & 17 & 2,478 & & \\
\hline 15 & FHIT & $1,504,176$ & 10 & 3,116 & FRA3B & \\
\hline 16 & AGBL4 & $1,491,101$ & 14 & 2,989 & & \\
\hline 17 & CCSER1 & $1,474,329$ & 11 & 5,847 & & \\
\hline 18 & GRID2 & $1,470,601$ & 16 & 5,783 & FRA4G & Glutamate receptor \\
\hline 19 & GPC5 & $1,468,617$ & 8 & 2,943 & FRA13D & \\
\hline 20 & CTNNA2 & $1,463,549$ & 22 & 4,349 & FRA2E & \\
\hline 21 & MAGI2 & $1,436,613$ & 22 & 6,975 & & \\
\hline 22 & RBMS3 & $1,427,860$ & 17 & 1,973 & & \\
\hline 23 & AC098650.1 & $1,418,360$ & 14 & 3,535 & & \\
\hline 24 & DPP10 & $1,403,454$ & 26 & 5,964 & & \\
\hline 25 & PRKN & $1,380,350$ & 12 & 4,178 & FRA6E & Parkinson's disease \\
\hline 26 & IL1RAPL1 & $1,369,273$ & 11 & 3,615 & FRAXC & \\
\hline 27 & LRRC4C & $1,345,481$ & 5 & 2,669 & & \\
\hline 28 & AF241726.2 & $1,338,345$ & 9 & 954 & & \\
\hline 29 & CNTN5 & $1,337,937$ & 25 & 6,499 & & \\
\hline 30 & PRKG1 & $1,307,463$ & 18 & 6,957 & FRA10C & \\
\hline 31 & TBC1D5 & $1,284,446$ & 22 & 7,854 & & \\
\hline 32 & $\mathrm{PCDH} 15$ & $1,249,127$ & 28 & 9,366 & & \\
\hline 33 & ANKS1B & $1,248,816$ & 17 & 6,874 & & \\
\hline 34 & GALNTL6 & $1,228,156$ & 9 & 2,370 & & \\
\hline 35 & KAZN & $1,225,252$ & 71 & 1,3052 & & \\
\hline 36 & KCNIP4 & $1,220,167$ & 11 & 3,101 & & \\
\hline 37 & NRG1+ & $1,215,008$ & 12 & 5,931 & & \\
\hline 38 & CSMD3 & $1,214,012$ & 19 & 7,469 & & \\
\hline 39 & IL1RAPL2 & $1,201,631$ & 9 & 7,121 & & \\
\hline 40 & DCC $\ddagger$ & $1,195,703$ & 19 & 10,181 & FRA18B & \\
\hline
\end{tabular}

*APOE/LRP signaling

†Integrin signaling

‡ APP/Netrin-1 signaling 213

\section{Long gene vulnerability and the amyloid cascade theory}

The APP molecule is probably one member of a large synaptic adhesion interactome, rather than a central disease factor (Fig. 1). Some members of this interactome may be vulnerable to DNA damage in aging, causing others to appear as disease risk loci. For example, mutational loss of 
the LRP1b gene, whose protein product binds APP and affects its cleavage ${ }^{192}$, may increase A $\beta$ generation as an indirect effect of DNA damage. As noted for its closest homolog LRP1 $1^{97-100}$, another potential consequence of this event is $\beta 1$ integrin dysfunction, with Tau phosphorylation taking place in this cascade ${ }^{98}$. Taken together, neuropathology and the proteinopathy in AD may represent consequences of altered signaling events, rather than causal factors. Following this assumption, the current hypothesis is incompatible with the amyloid cascade theory.

\section{Glial cells, innate and adaptive immunity and the complement system}

As a part of the innate immune system, the complement cascade controls synaptic pruning in the developing brain and in psychiatric disorders by tagging unwanted synapses for removal ${ }^{214}$. Microglia cells recognize activated complement proteins deposited on the synapse via a ligandreceptor interaction ${ }^{215}$. The genetic architecture of $\mathrm{AD}$ seems to implicate some degree of overlap between glial-specific genes and neurodegeneration. In support of the complement system and its potential role $\mathrm{AD}$, the extremely long and fragile synapses gene, CSMD1, prevents complement activation (please see above). Nevertheless, it remains unknown whether neuroinflammation is a cause or a consequence of the disease pathogenesis mechanisms. Notably, somatic mutations in cancer cells result in the generation of novel peptides (neoantigens) that are unknown to the immune system and elicit an immune response ${ }^{216}$. Whether somatic mutations in synaptic genes may cause immune activation remains an open and interesting question.

\section{Conclusion}

Aging is associated with an accumulation of random 'hits' to the DNA base sequence in the form of DNA damage, CNVs, SNVs and other types of somatic mutations. This process can result in carcinogenesis in mitotically active cells, but its effects have yet to be understood in post-mitotic neurons. Long synaptic genes may be more vulnerable to this random process and form a bottleneck in healthy brain aging, since they contain more 'information' (lower entropy) that is more probable to be lost in time. In addition, long genes often map to chromosomal fragile sites and mutational hotspots. Compared to healthy individuals, the pace of the mutational accumulation may be higher in $\mathrm{AD}$ patients, and/or the resistance threshold of neurons to such harmful effects of aging may be lower, causing earlier cell death or dysfunction. Long gene vulnerability warrants new disease modification strategies for the treatment of AD.

\section{Acknowledgements}

I am thankful to Tristan Looden, Saige Rutherford and Christienne Damatac for their help with this manuscript. 


\section{References}

1 Glenner, G. G. \& Wong, C. W. Alzheimer's disease: initial report of the purification and characterization of a novel cerebrovascular amyloid protein. Biochemical and biophysical research communications 120, 885-890 (1984).

2 Hardy, J. A. \& Higgins, G. A. Alzheimer's disease: the amyloid cascade hypothesis. Science (New York, N.Y.) 256, 184-185 (1992).

3 Kang, J. et al. The precursor of Alzheimer's disease amyloid A4 protein resembles a cell-surface receptor. Nature 325, 733-736 (1987).

$4 \quad$ Müller, T. et al. Modulation of gene expression and cytoskeletal dynamics by the amyloid precursor protein intracellular domain (AICD). Molecular biology of the cell 18, 201-210 (2007).

5 Deyts, C., Thinakaran, G. \& Parent, A. T. APP Receptor? To Be or Not To Be. Trends Pharmacol Sci 37, 390-411, doi:10.1016/j.tips.2016.01.005 (2016).

6 Steubler, V. et al. Loss of all three APP family members during development impairs synaptic function and plasticity, disrupts learning, and causes an autism-like phenotype. e107471 (2021).

7 Gatz, M. et al. Role of genes and environments for explaining Alzheimer disease. Archives of general psychiatry 63, 168-174, doi:10.1001/archpsyc.63.2.168 (2006).

8 Reiman, E. M. et al. GAB2 Alleles Modify Alzheimer's Risk in APOE $\varepsilon 4$ Carriers. Neuron 54, 713720, doi:10.1016/j.neuron.2007.05.022 (2007).

9 Lambert, J. C. et al. Meta-analysis of 74,046 individuals identifies 11 new susceptibility loci for Alzheimer's disease. Nature genetics 45, 1452-1458, doi:10.1038/ng.2802 (2013).

10 Jansen, I. E. et al. Genome-wide meta-analysis identifies new loci and functional pathways influencing Alzheimer's disease risk. (2019).

11 Soheili-Nezhad, S. et al. Imaging genomics discovery of a new risk variant for Alzheimer's disease in the postsynaptic SHARPIN gene. Human Brain Mapping (2020).

12 de Rojas, I., Moreno-Grau, S., Tesi, N. \& Grenier-Boley, B. Common variants in Alzheimer's disease: Novel association of six genetic variants with $A D$ and risk stratification by polygenic risk scores. medRxiv (2019).

13 Strittmatter, W. J. et al. Apolipoprotein E: high-avidity binding to beta-amyloid and increased frequency of type 4 allele in late-onset familial Alzheimer disease. Proc Natl Acad Sci U S A 90, 1977-1981, doi:10.1073/pnas.90.5.1977 (1993).

14 Tosto, G. \& Reitz, C. Genome-wide association studies in Alzheimer's disease: a review. Curr Neurol Neurosci Rep 13, 381-381, doi:10.1007/s11910-013-0381-0 (2013).

15 Dourlen, P., Kilinc, D., Malmanche, N., Chapuis, J. \& Lambert, J. C. The new genetic landscape of Alzheimer's disease: from amyloid cascade to genetically driven synaptic failure hypothesis? Acta Neuropathol 138, 221-236, doi:10.1007/s00401-019-02004-0 (2019).

16 Sims, R., Hill, M. \& Williams, J. The multiplex model of the genetics of Alzheimer's disease. Nat Neurosci 23, 311-322, doi:10.1038/s41593-020-0599-5 (2020).

17 Krishnan, D., Menon, R. N. \& Gopala, S. SHARPIN: Role in Finding NEMO and in Amyloid-Beta Clearance and Degradation (ABCD) Pathway in Alzheimer's Disease? Cellular and Molecular Neurobiology, 1-15 (2021).

18 Tse, K. H. \& Herrup, K. Re-imagining Alzheimer's disease-the diminishing importance of amyloid and a glimpse of what lies ahead. Journal of neurochemistry 143, 432-444 (2017).

19 Ricciarelli, R. \& Fedele, E. The Amyloid Cascade Hypothesis in Alzheimer's Disease: It's Time to Change Our Mind. Curr Neuropharmacol 15, 926-935, doi:10.2174/1570159X15666170116143743 (2017). 
Joseph, J. et al. Copernicus revisited: amyloid beta in Alzheimer's disease. Neurobiol Aging 22, 131-146, doi:10.1016/s0197-4580(00)00211-6 (2001).

21 Frigerio, I. et al. Amyloid- $\beta$, p-tau, and reactive microglia load are correlates of MRI cortical atrophy in Alzheimer's disease. 2021.2006.2016.448650, doi:10.1101/2021.06.16.448650 \%J bioRxiv (2021).

22 Coulson, E. J., Paliga, K., Beyreuther, K. \& Masters, C. L. What the evolution of the amyloid protein precursor supergene family tells us about its function. Neurochem Int 36, 175-184, doi:10.1016/s0197-0186(99)00125-4 (2000).

23 Ristori, E. et al. Amyloid- $\beta$ Precursor Protein APP Down-Regulation Alters Actin CytoskeletonInteracting Proteins in Endothelial Cells. Cells 9, doi:10.3390/cells9112506 (2020).

24 Kibbey, M. C. et al. beta-Amyloid precursor protein binds to the neurite-promoting IKVAV site of laminin. Proc Natl Acad Sci U S A 90, 10150-10153 (1993).

25 Breen, K. C. APP-collagen interaction is mediated by a heparin bridge mechanism. Molecular and chemical neuropathology 16, 109-121 (1992).

26 Li, X.-F., Thinakaran, G., Sisodia, S. S. \& Fu-Shin, X. Y. Amyloid precursor-like protein 2 promotes cell migration toward fibronectin and collagen IV. Journal of Biological Chemistry 274, 2724927256 (1999).

27 Small, D. H. et al. A heparin-binding domain in the amyloid protein precursor of Alzheimer's disease is involved in the regulation of neurite outgrowth. Journal of Neuroscience 14, 2117 2127 (1994). Sosa, L. J. et al. Amyloid precursor protein is an autonomous growth cone adhesion molecule engaged in contact guidance. PloS one 8, e64521, doi:10.1371/journal.pone.0064521 (2013).

29 McKerracher, L., Chamoux, M. \& Arregui, C. O. Role of laminin and integrin interactions in growth cone guidance. Mol Neurobiol 12, 95-116, doi:10.1007/bf02740648 (1996).

30 Young-Pearse, T. L., Chen, A. C., Chang, R., Marquez, C. \& Selkoe, D. J. Secreted APP regulates the function of full-length APP in neurite outgrowth through interaction with integrin beta1. Neural development 3, 15, doi:10.1186/1749-8104-3-15 (2008).

31 Yamazaki, T., Koo, E. H. \& Selkoe, D. J. Cell surface amyloid $\beta$-protein precursor colocalizes with $\beta 1$ integrins at substrate contact sites in neural cells. The Journal of neuroscience 17, 1004-1010 (1997).

32 Young-Pearse, T. L., Chen, A. C., Chang, R., Marquez, C. \& Selkoe, D. J. Secreted APP regulates the function of full-length APP in neurite outgrowth through interaction with integrin beta1. Neural Development 3, 15-15, doi:10.1186/1749-8104-3-15 (2008).

33 Sabo, S. L., Ikin, A. F., Buxbaum, J. D. \& Greengard, P. The Alzheimer amyloid precursor protein (APP) and FE65, an APP-binding protein, regulate cell movement. The Journal of cell biology 153, 1403-1414, doi:10.1083/jcb.153.7.1403 (2001).

34 Hoe, H. S. et al. Interaction of reelin with amyloid precursor protein promotes neurite outgrowth. The Journal of neuroscience : the official journal of the Society for Neuroscience 29, 7459-7473, doi:10.1523/jneurosci.4872-08.2009 (2009).

35 Stanco, A. et al. Netrin-1- $\alpha 3 \beta 1$ integrin interactions regulate the migration of interneurons through the cortical marginal zone. Proceedings of the National Academy of Sciences 106, 75957600, doi:10.1073/pnas.0811343106 (2009).

36 Rama, N. et al. Amyloid precursor protein regulates netrin-1-mediated commissural axon outgrowth. The Journal of biological chemistry 287, 30014-30023, doi:10.1074/jbc.M111.324780 (2012).

37 Lourenco, F. C. et al. Netrin-1 interacts with amyloid precursor protein and regulates amyloidbeta production. Cell death and differentiation 16, 655-663, doi:10.1038/cdd.2008.191 (2009). 
Matos, M. F. et al. Autoinhibition of Mint1 adaptor protein regulates amyloid precursor protein binding and processing. Proc Nat Acad Sci U S A 109, 3802-3807, doi:10.1073/pnas.1119075109 (2012).

39 Young-Pearse, T. L. et al. A critical function for beta-amyloid precursor protein in neuronal migration revealed by in utero RNA interference. The Journal of neuroscience : the official journal of the Society for Neuroscience 27, 14459-14469, doi:10.1523/jneurosci.4701-07.2007 (2007). Minami, S. S., Hoe, H.-S. \& Rebeck, G. W. Fyn kinase regulates the association between amyloid precursor protein and Dab1 by promoting their localization to detergent-resistant membranes. Journal of neurochemistry 118, 879-890, doi:10.1111/j.1471-4159.2011.07296.x (2011).

41 Shariati, S. A. M. \& De Strooper, B. Redundancy and divergence in the amyloid precursor protein family. FEBS letters 587, 2036-2045 (2013).

$42 \mathrm{Li}, \mathrm{H}$. et al. Structural basis of kindlin-mediated integrin recognition and activation. Proceedings of the National Academy of Sciences 114, 9349-9354, doi:10.1073/pnas.1703064114 (2017).

43 Smirnova, E. et al. Solution Structure and Peptide Binding of the PTB Domain from the AIDA1 Postsynaptic Signaling Scaffolding Protein. PloS one 8, e65605, doi:10.1371/journal.pone.0065605 (2013).

44 Tindi, J. O. et al. ANKS1B Gene Product AIDA-1 Controls Hippocampal Synaptic Transmission by Regulating GluN2B Subunit Localization. The Journal of neuroscience : the official journal of the Society for Neuroscience 35, 8986-8996, doi:10.1523/jneurosci.4029-14.2015 (2015). Stahl, R. et al. Shedding of APP limits its synaptogenic activity and cell adhesion properties. Frontiers in Cellular Neuroscience 8, 410, doi:10.3389/fncel.2014.00410 (2014).

46 Cousins, S. L., Hoey, S. E., Anne Stephenson, F. \& Perkinton, M. S. Amyloid precursor protein 695 associates with assembled NR2A- and NR2B-containing NMDA receptors to result in the enhancement of their cell surface delivery. J Neurochem 111, 1501-1513, doi:10.1111/j.14714159.2009.06424.x (2009).

47 Hoe, H.-S. et al. The Effects of Amyloid Precursor Protein on Postsynaptic Composition and Activity. The Journal of biological chemistry 284, 8495-8506, doi:10.1074/jbc.M900141200 (2009).

48 McGeachie, A. B., Cingolani, L. A. \& Goda, Y. Stabilising influence: integrins in regulation of synaptic plasticity. Neurosci Res 70, 24-29, doi:10.1016/j.neures.2011.02.006 (2011).

49 Chan, C.-S. et al. Beta 1-integrins are required for hippocampal AMPA receptor-dependent synaptic transmission, synaptic plasticity, and working memory. The Journal of neuroscience : the official journal of the Society for Neuroscience 26, 223-232, doi:10.1523/JNEUROSCI.411005.2006 (2006).

50 Sun, Y. et al. Fe65 Suppresses Breast Cancer Cell Migration and Invasion through Tip60 Mediated Cortactin Acetylation. Scientific reports 5 (2015).

51 Bakshi, K. et al. Novel complex of HAT protein TIP60 and nuclear receptor PXR promotes cell migration and adhesion. Scientific reports 7, 3635 (2017).

52 Sabo, S. L., Ikin, A. F., Buxbaum, J. D. \& Greengard, P. The Alzheimer amyloid precursor protein (APP) and FE65, an APP-binding protein, regulate cell movement. J Cell Biol 153, 1403-1414, doi:10.1083/jcb.153.7.1403 (2001).

53 Zhou, B., Liu, L., Reddivari, M. \& Zhang, X. A. The Palmitoylation of Metastasis Suppressor KAI1/CD82 Is Important for Its Motility- and Invasiveness-Inhibitory Activity. Cancer Research 64, 7455-7463, doi:10.1158/0008-5472.can-04-1574 (2004).

54 Liu, W. M. et al. Tetraspanin CD82 inhibits protrusion and retraction in cell movement by attenuating the plasma membrane-dependent actin organization. PloS one 7, e51797, doi:10.1371/journal.pone.0051797 (2012). 
Jee, B. K., Lee, J. Y., Lim, Y., Lee, K. H. \& Jo, Y. H. Effect of KAI1/CD82 on the beta1 integrin maturation in highly migratory carcinoma cells. Biochem Biophys Res Commun 359, 703-708, doi:10.1016/j.bbrc.2007.05.159 (2007).

56 Steinecke, A., Gampe, C., Nitzsche, F. \& Bolz, J. DISC1 knockdown impairs the tangential migration of cortical interneurons by affecting the actin cytoskeleton. Front Cell Neurosci 8, 190, doi:10.3389/fncel.2014.00190 (2014).

57 Young-Pearse, T. L., Suth, S., Luth, E. S., Sawa, A. \& Selkoe, D. J. Biochemical and functional interaction of DISC1 and APP regulates neuronal migration during mammalian cortical development. The Journal of neuroscience : the official journal of the Society for Neuroscience 30, 10431-10440, doi:10.1523/JNEUROSCI.1445-10.2010 (2010).

58 Hattori, T. et al. DISC1 regulates cell-cell adhesion, cell-matrix adhesion and neurite outgrowth. Mol Psychiatry 15, 778, 798-809, doi:10.1038/mp.2010.60 (2010).

59 Suetsugu, S. et al. Regulation of actin cytoskeleton by mDab1 through N-WASP and ubiquitination of mDab1. Biochemical Journal 384, 1-8 (2004).

60 Schmid, R. S., Jo, R., Shelton, S., Kreidberg, J. A. \& Anton, E. S. Reelin, integrin and DAB1 interactions during embryonic cerebral cortical development. Cereb Cortex 15, 1632-1636, doi:10.1093/cercor/bhi041 (2005).

61 Minami, S. S. et al. The cytoplasmic adaptor protein X11 $\alpha$ and extracellular matrix protein Reelin regulate ApoE receptor 2 trafficking and cell movement. The FASEB Journal 24, 58-69, doi:10.1096/fj.09-138123 (2010).

62 Cheng, S. Y. S., Sun, G., Schlaepfer, D. D. \& Pallen, C. J. Grb2 Promotes Integrin-Induced Focal Adhesion Kinase (FAK) Autophosphorylation and Directs the Phosphorylation of Protein Tyrosine Phosphatase $\alpha$ by the Src-FAK Kinase Complex. Mol Cell Biol 34, 348-361, doi:10.1128/MCB.00825-13 (2014).

63 Giubellino, A., Burke, T. R. \& Bottaro, D. P. Grb2 Signaling in Cell Motility and Cancer. Expert opinion on therapeutic targets 12, 1021-1033, doi:10.1517/14728222.12.8.1021 (2008).

64 Mauro, L. et al. SHC- $\alpha 5 \beta 1$ Integrin Interactions Regulate Breast Cancer Cell Adhesion and Motility. Experimental cell research 252, 439-448 (1999).

65 Wary, K. K., Mainiero, F., Isakoff, S. J., Marcantonio, E. E. \& Giancotti, F. G. The adaptor protein Shc couples a class of integrins to the control of cell cycle progression. Cell 87, 733-743, doi:10.1016/s0092-8674(00)81392-6 (1996).

66 Han, D. C., Shen, T.-L. \& Guan, J.-L. Role of Grb7 targeting to focal contacts and its phosphorylation by focal adhesion kinase in regulation of cell migration. Journal of Biological Chemistry 275, 28911-28917 (2000).

67 Han, D. C. \& Guan, J. L. Association of focal adhesion kinase with Grb7 and its role in cell migration. The Journal of biological chemistry 274, 24425-24430, doi:10.1074/jbc.274.34.24425 (1999).

68 Roy, N. H., MacKay, J. L., Robertson, T. F., Hammer, D. A. \& Burkhardt, J. K. Crk adaptor proteins mediate actin-dependent T cell migration and mechanosensing induced by the integrin LFA-1. Science Signaling 11, eaat3178, doi:10.1126/scisignal.aat3178 (2018).

69 Gustavsson, A., Yuan, M. \& Fällman, M. Temporal dissection of $\beta 1$-integrin signaling indicates a role for p130Cas-Crk in filopodia formation. Journal of Biological Chemistry 279, 22893-22901 (2004).

70 Chuang, H.-H. et al. Pin1 Is Involved in HDAC6-mediated Cancer Cell Motility. International journal of medical sciences 15, 1573 (2018).

71 Lee, K.-J. et al. CD99-Derived Agonist Ligands Inhibit Fibronectin-Induced Activation of $\beta 1$ Integrin through the Protein Kinase A/SHP2/Extracellular Signal-Regulated Kinase/PTPN12/Focal 
Adhesion Kinase Signaling Pathway. Mol Cell Bio/ 37, e00675-00616, doi:10.1128/mcb.00675-16 (2017).

72 Mathis, C., Schröter, A., Thallmair, M. \& Schwab, M. E. Nogo-a regulates neural precursor migration in the embryonic mouse cortex. Cerebral cortex 20, 2380-2390 (2010).

73 lobbi, C., Korte, M. \& Zagrebelsky, M. Nogo-66 Restricts Synaptic Strengthening via Lingo1 and the ROCK2-Cofilin Pathway to Control Actin Dynamics. Cerebral Cortex 27, 2779-2792, doi:10.1093/cercor/bhw122 (2016). Differentiation by Blocking the $\beta$-integrin Signaling Pathway (P5.298). Neurology 86, P5.298 (2016). Rice, H. C. et al. Pancortins interact with amyloid precursor protein and modulate cortical cell migration. Development 139, 3986-3996, doi:10.1242/dev.082909 (2012). (2000). regulates epithelial cell adhesion and migration. Developmental cell 5, 695-707 (2003). Kang, D. S. et al. Netrin-1/DCC-mediated PLC $\gamma 1$ activation is required for axon guidance and brain structure development. EMBO reports 19, e46250 (2018). Stanco, A. et al. Netrin-1- $\alpha 3 \beta 1$ integrin interactions regulate the migration of interneurons through the cortical marginal zone. Proceedings of the National Academy of Sciences 106, 75957600 (2009).

80 Klar, A., Baldassare, M. \& Jessell, T. M. F-spondin: a gene expressed at high levels in the floor plate encodes a secreted protein that promotes neural cell adhesion and neurite extension. Cell 69, 95-110 (1992).

81 Oka, H., Mori, M. \& Kihara, H. F-spondin inhibits migration and differentiation of osteoclastic precursors. Journal of periodontology 82, 1776-1783 (2011).

82 Terai, Y. et al. Vascular smooth muscle cell growth-promoting factor/F-spondin inhibits angiogenesis via the blockade of integrin $\alpha v \beta 3$ on vascular endothelial cells. Journal of cellular physiology 188, 394-402 (2001).

83 Hemming, M. L., Elias, J. E., Gygi, S. P. \& Selkoe, D. J. Proteomic profiling of $\gamma$-secretase substrates and mapping of substrate requirements. PLoS Bio/ 6, e257 (2008).

84 De Strooper, B. et al. A presenilin-1-dependent $\mathrm{\gamma}$-secretase-like protease mediates release of Notch intracellular domain. Nature 398, 518-522 (1999).

85 Guerreiro, R. J. et al. Exome sequencing reveals an unexpected genetic cause of disease: NOTCH3 mutation in a Turkish family with Alzheimer's disease. Neurobiol Aging 33, 1008.e1017-1023, doi:10.1016/j.neurobiolaging.2011.10.009 (2012).

86 Liu, C.-X., Ranganathan, S., Robinson, S. \& Strickland, D. K. gamma-Secretase-mediated release of the low density lipoprotein receptor-related protein $1 \mathrm{~B}$ intracellular domain suppresses anchorage-independent growth of neuroglioma cells. The Journal of biological chemistry $\mathbf{2 8 2}$, 7504-7511, doi:10.1074/jbc.m608088200 (2007).

87 Atapattu, L., Lackmann, M. \& Janes, P. W. The role of proteases in regulating Eph/ephrin signaling. Cell adhesion \& migration 8, 294-307 (2014).

88 Yoon, Y. et al. PS1 FAD mutants decrease ephrinB2-regulated angiogenic functions, ischemiainduced brain neovascularization and neuronal survival. Molecular Psychiatry, doi:10.1038/s41380-020-0812-7 (2020).

89 Meyer, S., Orsó, E., Schmitz, G., Landthaler, M. \& Vogt, T. Lubrol-RAFTs in Melanoma Cells: A Molecular Platform for Tumor-Promoting Ephrin-B2-Integrin- $\beta 1$ Interaction. Journal of investigative dermatology 127, 1615-1621 (2007). 
90 Hoe, H.-S. et al. Interaction of reelin with amyloid precursor protein promotes neurite outgrowth. Journal of Neuroscience 29, 7459-7473 (2009).

91 Schedin-Weiss, S., Caesar, I., Winblad, B., Blom, H. \& Tjernberg, L. O. Super-resolution microscopy reveals $\gamma$-secretase at both sides of the neuronal synapse. Acta Neuropathologica Communications 4, 29, doi:10.1186/s40478-016-0296-5 (2016).

92 Restituito, S. et al. Synaptic Autoregulation by Metalloproteases and $\gamma$-Secretase. The Journal of neuroscience : the official journal of the Society for Neuroscience 31, 12083-12093, doi:10.1523/JNEUROSCI.2513-11.2011 (2011).

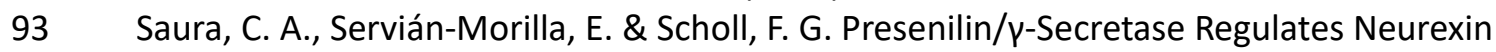
Processing at Synapses. PloS one 6, e19430, doi:10.1371/journal.pone.0019430 (2011).

94 Waschbüsch, D. et al. Presenilin 1 affects focal adhesion site formation and cell force generation via c-Src transcriptional and posttranslational regulation. J Biol Chem 284, 10138-10149, doi:10.1074/jbc.M806825200 (2009).

95 Bai, G. et al. Presenilin-Dependent Receptor Processing Is Required for Axon Guidance. Cell 144, 106-118, doi:http://dx.doi.org/10.1016/j.cell.2010.11.053 (2011).

96 Lambert, J.-C. et al. Genome-wide association study identifies variants at CLU and CR1 associated with Alzheimer's disease. Nature genetics 41, 1094-1099, doi:10.1038/ng.439 (2009).

97 Mills, J. et al. Role of integrin-linked kinase in nerve growth factor-stimulated neurite outgrowth. Journal of Neuroscience 23, 1638-1648 (2003).

98 Ishii, T., Furuoka, H., Muroi, Y. \& Nishimura, M. Inactivation of integrin-linked kinase induces aberrant tau phosphorylation via sustained activation of glycogen synthase kinase $3 \beta$ in N1E-115 neuroblastoma cells. Journal of Biological Chemistry 278, 26970-26975 (2003).

99 Elie, A. et al. Tau co-organizes dynamic microtubule and actin networks. Scientific Reports 5, 9964, doi:10.1038/srep09964 (2015).

100 Biswas, S. \& Kalil, K. The Microtubule-Associated Protein Tau Mediates the Organization of Microtubules and Their Dynamic Exploration of Actin-Rich Lamellipodia and Filopodia of Cortical Growth Cones. The Journal of Neuroscience 38, 291-307, doi:10.1523/jneurosci.2281-17.2017 (2018).

101 Cabrales Fontela, Y. et al. Multivalent cross-linking of actin filaments and microtubules through the microtubule-associated protein Tau. Nature Communications 8, 1981, doi:10.1038/s41467017-02230-8 (2017).

102 Bellenguez, C. et al. New insights on the genetic etiology of Alzheimer's and related dementia. medRxiv, 2020.2010.2001.20200659, doi:10.1101/2020.10.01.20200659 (2020).

103 Jehle, A. W. et al. ATP-binding cassette transporter A7 enhances phagocytosis of apoptotic cells and associated ERK signaling in macrophages. The Journal of cell biology 174, 547-556 (2006).

104 Man, H.-Y. et al. Regulation of AMPA receptor-mediated synaptic transmission by clathrindependent receptor internalization. 25, 649-662 (2000).

105 Gao, J. et al. The E3 ubiquitin ligase IDOL regulates synaptic ApoER2 levels and is important for plasticity and learning. 6, e29178 (2017).

106 May, P. et al. Neuronal LRP1 functionally associates with postsynaptic proteins and is required for normal motor function in mice. Mol Cell Biol 24, 8872-8883, doi:10.1128/MCB.24.20.88728883.2004 (2004).

107 Beffert, U. et al. Modulation of synaptic plasticity and memory by Reelin involves differential splicing of the lipoprotein receptor Apoer2. Neuron 47, 567-579, doi:10.1016/j.neuron.2005.07.007 (2005).

108 Maginnis, M. S. et al. NPXY motifs in the beta1 integrin cytoplasmic tail are required for functional reovirus entry. J Virol 82, 3181-3191, doi:10.1128/JVI.01612-07 (2008). 
109 Wujak, L. et al. Low density lipoprotein receptor-related protein 1 couples $\beta 1$ integrin activation to degradation. Cell Mol Life Sci 75, 1671-1685, doi:10.1007/s00018-017-2707-6 (2018).

110 Dong, Y. et al. Downregulation of EphA1 in colorectal carcinomas correlates with invasion and metastasis. Modern Pathology 22, 151-160 (2009).

111 Carter, N., Nakamoto, T., Hirai, H. \& Hunter, T. EphrinA1-induced cytoskeletal re-organization requires FAK and p130cas. Nature cell biology 4, 565-573 (2002).

112 Yamazaki, T. et al. EphA1 interacts with integrin-linked kinase and regulates cell morphology and motility. Journal of cell science 122, 243-255, doi:10.1242/jcs.036467 (2009).

113 Goldie, S. J. et al. FRMD4A upregulation in human squamous cell carcinoma promotes tumor growth and metastasis and is associated with poor prognosis. Cancer research 72, 3424-3436 (2012).

114 Moleirinho, S., Tilston-Lunel, A., Angus, L., Gunn-Moore, F. \& Reynolds, Paul A. The expanding family of FERM proteins. Biochemical Journal 452, 183-193, doi:10.1042/bj20121642 (2013).

115 Frame, M. C., Patel, H., Serrels, B., Lietha, D. \& Eck, M. J. The FERM domain: organizing the structure and function of FAK. Nat. Rev. Mol. Cell Biol. 11, 802-814 (2010).

116 Ikenouchi, J. \& Umeda, M. FRMD4A regulates epithelial polarity by connecting Arf6 activation with the PAR complex. Proc Natl Acad Sci U S A 107, 748-753, doi:10.1073/pnas.0908423107 (2010).

117 Shen, Z. et al. Kindlin-2: a novel adhesion protein related to tumor invasion, lymph node metastasis, and patient outcome in gastric cancer. The American Journal of Surgery 203, 222-229 (2012).

118 Yu, W. M., Hawley, T. S., Hawley, R. G. \& Qu, C. K. Role of the docking protein Gab2 in beta(1)integrin signaling pathway-mediated hematopoietic cell adhesion and migration. Blood 99, 23512359, doi:10.1182/blood.v99.7.2351 (2002).

119 Herrera Abreu, M. T. et al. Gab2 regulates cytoskeletal organization and migration of mammary epithelial cells by modulating RhoA activation. Molecular biology of the cell 22, 105-116, doi:10.1091/mbc.E10-03-0185 (2011).

120 Huang, Z., Yazdani, U., Thompson-Peer, K. L., Kolodkin, A. L. \& Terman, J. R. Crk-associated substrate (Cas) signaling protein functions with integrins to specify axon guidance during development. Development 134, 2337-2347, doi:10.1242/dev.004242 (2007).

121 Singh, M. K. et al. A novel Cas family member, HEPL, regulates FAK and cell spreading. Mol Biol Cell 19, 1627-1636, doi:10.1091/mbc.E07-09-0953 (2008).

122 Guerrero, M. S., Parsons, J. T. \& Bouton, A. H. Cas and NEDD9 contribute to tumor progression through dynamic regulation of the cytoskeleton. Genes \& cancer 3, 371-381 (2012).

123 Reiser, J. et al. Podocyte migration during nephrotic syndrome requires a coordinated interplay between cathepsin L and alpha3 integrin. The Journal of biological chemistry 279, 34827-34832, doi:10.1074/jbc.M401973200 (2004).

124 van Duijn, T. J., Anthony, E. C., Hensbergen, P. J., Deelder, A. M. \& Hordijk, P. L. Rac1 Recruits the Adapter Protein CMS/CD2AP to Cell-Cell Contacts. The Journal of biological chemistry 285, 20137-20146, doi:10.1074/jbc.M109.099481 (2010).

125 Lipinski, C. A. et al. The tyrosine kinase pyk2 promotes migration and invasion of glioma cells. Neoplasia 7, 435-445 (2005).

126 Taniyama, Y. et al. Pyk2- and Src-dependent tyrosine phosphorylation of PDK1 regulates focal adhesions. Mol Cell Biol 23, 8019-8029, doi:10.1128/mcb.23.22.8019-8029.2003 (2003).

127 Mondal, S., Subramanian, K. K., Sakai, J., Bajrami, B. \& Luo, H. R. Phosphoinositide lipid phosphatase SHIP1 and PTEN coordinate to regulate cell migration and adhesion. Mol Biol Cell 23, 1219-1230, doi:10.1091/mbc.E11-10-0889 (2012). 
128 Maxwell, M. J. et al. SHIP1 and Lyn Kinase Negatively Regulate Integrin alpha Ilb beta 3 signaling in platelets. The Journal of biological chemistry 279, 32196-32204, doi:10.1074/jbc.M400746200 (2004).

129 Peng, Q. et al. TREM2- and DAP12-Dependent Activation of PI3K Requires DAP10 and Is Inhibited by SHIP1. Science Signaling 3, ra38-ra38, doi:10.1126/scisignal.2000500 (2010).

130 Wang, S. et al. Nyap1 regulates multipolar - bipolar transition and morphology of migrating neurons by Fyn phosphorylation during corticogenesis. doi:10.1093/cercor/bhz137 (2019).

131 Yokoyama, K. et al. NYAP: a phosphoprotein family that links PI3K to WAVE1 signalling in neurons. EMBO J 30, 4739-4754, doi:10.1038/emboj.2011.348 (2011).

132 Lionello, V. M. et al. Amphiphysin 2 modulation rescues myotubular myopathy and prevents focal adhesion defects in mice. Science Translational Medicine 11, eaav1866, doi:10.1126/scitransImed.aav1866 (2019).

133 Mundigl, O. et al. Amphiphysin I antisense oligonucleotides inhibit neurite outgrowth in cultured hippocampal neurons. The Journal of neuroscience : the official journal of the Society for Neuroscience 18, 93-103 (1998).

134 Wixler, V. et al. Identification of novel interaction partners for the conserved membrane proximal region of alpha-integrin cytoplasmic domains. FEBS Lett 445, 351-355, doi:10.1016/s00145793(99)00151-9 (1999).

135 Messina, S. et al. Specific interactions of neuronal focal adhesion kinase isoforms with Src kinases and amphiphysin. J Neurochem 84, 253-265, doi:10.1046/j.1471-4159.2003.01519.x (2003).

136 Drager, N. M. et al. Bin1 directly remodels actin dynamics through its BAR domain. EMBO Rep 18, 2051-2066, doi:10.15252/embr.201744137 (2017).

137 Tebar, F., Bohlander, S. K. \& Sorkin, A. Clathrin assembly lymphoid myeloid leukemia (CALM) protein: localization in endocytic-coated pits, interactions with clathrin, and the impact of overexpression on clathrin-mediated traffic. Molecular biology of the cell 10, 2687-2702 (1999).

138 Man, H. Y. et al. Regulation of AMPA receptor-mediated synaptic transmission by clathrindependent receptor internalization. Neuron 25, 649-662 (2000).

139 Hines, J. H., Abu-Rub, M. \& Henley, J. R. Asymmetric endocytosis and remodeling of beta1integrin adhesions during growth cone chemorepulsion by MAG. Nature neuroscience 13, 829837, doi:10.1038/nn.2554 (2010).

140 Caswell, P. \& Norman, J. Endocytic transport of integrins during cell migration and invasion. Trends Cell Biol 18, 257-263, doi:10.1016/j.tcb.2008.03.004 (2008).

141 Becker, T. et al. COMPREHENSIVE GENE-GENE INTERACTION META-ANALYSIS OF IGAP GWA STUDIES. Alzheimer's \& Dementia: The Journal of the Alzheimer's Association 10, P245, doi:10.1016/j.jalz.2014.04.375.

142 Royle, S. J. \& Lagnado, L. Clathrin-mediated endocytosis at the synaptic terminal: bridging the gap between physiology and molecules. Traffic 11, 1489-1497 (2010).

143 Hashimoto, Y., Toyama, Y., Kusakari, S., Nawa, M. \& Matsuoka, M. An Alzheimer Disease-linked Rare Mutation Potentiates Netrin Receptor Uncoordinated-5C-induced Signaling That Merges with Amyloid $\beta$ Precursor Protein Signaling. The Journal of biological chemistry 291, 12282 12293, doi:10.1074/jbc.M115.698092 (2016).

144 Yuan, M. et al. UNC5C-knockdown enhances the growth and metastasis of breast cancer cells by potentiating the integrin $\alpha 6 / \beta 4$ signaling pathway. International Journal of Oncology 56, 139-150 (2020).

145 Carsberg, C. J., Myers, K. A. \& Stern, P. L. Metastasis-associated 5 T4 antigen disrupts cell-cell contacts and induces cellular motility in epithelial cells. International journal of cancer 68, 84-92, doi:10.1002/(sici)1097-0215(19960927)68:1<84::aid-ijc15>3.0.co;2-6 (1996). 
146 He, P. et al. Trophoblast glycoprotein promotes pancreatic ductal adenocarcinoma cell metastasis through Wnt/planar cell polarity signaling. Molecular medicine reports 12, 503-509 (2015).

147 Spencer, H. L. et al. E-Cadherin Inhibits Cell Surface Localization of the Pro-Migratory 5T4 Oncofetal Antigen in Mouse Embryonic Stem Cells. Molecular Biology of the Cell 18, 2838-2851, doi:10.1091/mbc.E06-09-0875 (2007).

148 Murakami, T. et al. Trophoblast glycoprotein: possible candidate mediating podocyte injuries in glomerulonephritis. American journal of nephrology 32, 505-521 (2010).

149 Su, Y., Yang, J. \& Besner, G. E. HB-EGF promotes intestinal restitution by affecting integrinextracellular matrix interactions and intercellular adhesions. Growth Factors 31, 39-55 (2013).

150 Su, Y. \& Besner, G. E. HB-EGF Promotes Cell Migration and Adhesion via Focal Adhesion Kinase. The Journal of surgical research 189, 222-231, doi:10.1016/j.jss.2014.02.055 (2014).

151 Palamidessi, A. et al. The GTPase-activating protein RN-tre controls focal adhesion turnover and cell migration. Curr. Biol. 23, 2355-2364, doi:10.1016/j.cub.2013.09.060 (2013).

152 Zou, W. \& Teitelbaum, S. L. Absence of Dap12 and the $\alpha \mathrm{v} \beta 3$ integrin causes severe osteopetrosis. The Journal of cell biology 208, 125-136, doi:10.1083/jcb.201410123 (2014).

153 Dey-Guha, I. et al. A mechanism for asymmetric cell division resulting in proliferative asynchronicity. Mol Cancer Res 13, 223-230, doi:10.1158/1541-7786.Mcr-14-0474 (2015).

154 Berto, G. E. et al. The DCR Protein TTC3 Affects Differentiation and Golgi Compactness in Neurons through Specific Actin-Regulating Pathways. PloS one 9, e93721, doi:10.1371/journal.pone.0093721 (2014).

155 Tvorogov, D., Wang, X.-J., Zent, R. \& Carpenter, G. Integrin-dependent PLC- $\gamma 1$ phosphorylation mediates fibronectin-dependent adhesion. Journal of cell science 118, 601-610 (2005).

156 Mueller, H. et al. Tyrosine kinase Btk regulates E-selectin-mediated integrin activation and neutrophil recruitment by controlling phospholipase $C$ (PLC) $\gamma 2$ and PI3K $\gamma$ pathways. Blood 115, 3118-3127 (2010).

157 Ichigotani, Y., Yokozaki, S., Fukuda, Y., Hamaguchi, M. \& Matsuda, S. Forced expression of NESH suppresses motility and metastatic dissemination of malignant cells. Cancer Res 62, 2215-2219 (2002).

158 Hodgkinson, C. P. et al. Abi3bp is a multifunctional autocrine/paracrine factor that regulates mesenchymal stem cell biology. Stem Cells 31, 1669-1682, doi:10.1002/stem.1416 (2013).

159 Hodgkinson, C. P. et al. Abi3bp regulates cardiac progenitor cell proliferation and differentiation. Circ Res 115, 1007-1016, doi:10.1161/circresaha.115.304216 (2014).

160 Sekino, S. et al. The NESH/Abi-3-based WAVE2 complex is functionally distinct from the Abi-1based WAVE2 complex. Cell Commun Signal 13, 41-41, doi:10.1186/s12964-015-0119-5 (2015).

161 Moretti, R. M. et al. Molecular mechanisms of the antimetastatic activity of nuclear clusterin in prostate cancer cells. Int J Oncol 39, 225-234, doi:10.3892/ijo.2011.1030 (2011).

162 Leeb, C., Eresheim, C. \& Nimpf, J. Clusterin is a ligand for apolipoprotein E receptor 2 (ApoER2) and very low density lipoprotein receptor (VLDLR) and signals via the Reelin-signaling pathway. The Journal of biological chemistry 289, 4161-4172, doi:10.1074/jbc.M113.529271 (2014).

163 Pouwels, J. et al. SHARPIN regulates uropod detachment in migrating lymphocytes. Cell Rep 5, 619-628, doi:10.1016/j.celrep.2013.10.011 (2013).

164 Zhou, S. et al. SHARPIN promotes melanoma progression via Rap1 signaling pathway. Journal of Investigative Dermatology 140, 395-403. e396 (2020).

165 Rantala, J. K. et al. SHARPIN is an endogenous inhibitor of beta1-integrin activation. Nat Cell Biol 13, 1315-1324, doi:10.1038/ncb2340 (2011).

166 Lim, S. et al. Sharpin, a novel postsynaptic density protein that directly interacts with the shank family of proteins. Molecular and Cellular Neuroscience 17, 385-397 (2001). 
167 Siney, E. J. et al. Metalloproteinases ADAM10 and ADAM17 Mediate Migration and Differentiation in Glioblastoma Sphere-Forming Cells. Molecular neurobiology 54, 3893-3905, doi:10.1007/s12035-016-0053-6 (2017).

168 Rubinstein, E. et al. CD9, CD63, CD81, and CD82 are components of a surface tetraspan network connected to HLA-DR and VLA integrins. Eur J Immunol 26, 2657-2665, doi:10.1002/eji.1830261117 (1996).

169 Altomonte, M., Fonsatti, E., Visintin, A. \& Maio, M. Targeted therapy of solid malignancies via HLA class II antigens: a new biotherapeutic approach? Oncogene 22, 6564-6569 (2003).

170 Li, F., Zhang, X. \& Reed, E. F. 44-OR: HLA CLASS II (HLA II) LIGATION BY ANTIBODIES (Ab) INDUCES SIGNAL TRANSDUCTION AND CYTOSKELETON REORGANIZATION IN ENDOTHELIAL CELLS (EC). Human Immunology 73, 36 (2012).

171 Aljabri, A. et al. HLA class II antibodies induce necrotic cell death in human endothelial cells via a lysosomal membrane permeabilization-mediated pathway. Cell death \& disease 10, 1-15 (2019).

172 Chaki, S. P. et al. Nck enables directional cell migration through the coordination of polarized membrane protrusion with adhesion dynamics. Journal of cell science 126, 1637-1649 (2013).

$173 \mathrm{Tu}, \mathrm{Y}$., Li, F. \& Wu, C. Nck-2, a novel Src homology2/3-containing adaptor protein that interacts with the LIM-only protein PINCH and components of growth factor receptor kinase-signaling pathways. Molecular biology of the cell 9, 3367-3382 (1998).

174 Goicoechea, S. M. et al. Nck-2 interacts with focal adhesion kinase and modulates cell motility. The international journal of biochemistry \& cell biology 34, 791-805 (2002).

175 Wu, C. PINCH, N (i) ck and the ILK: network wiring at cell-matrix adhesions. Trends in cell biology 15, 460-466 (2005).

176 Clarke, N. E., Fisher, M. J., Porter, K. E., Lambert, D. W. \& Turner, A. J. Angiotensin converting enzyme (ACE) and ACE2 bind integrins and ACE2 regulates integrin signalling. PloS one 7, e34747 (2012).

177 Hong, M.-G., Pawitan, Y., Magnusson, P. K. \& Prince, J. A. Strategies and issues in the detection of pathway enrichment in genome-wide association studies. Human genetics 126, 289-301 (2009).

178 Zylka, M. J., Simon, J. M. \& Philpot, B. D. Gene length matters in neurons. Neuron 86, 353-355, doi:10.1016/j.neuron.2015.03.059 (2015).

179 Jang, S., Lee, H. \& Kim, E. Synaptic adhesion molecules and excitatory synaptic transmission. Current Opinion in Neurobiology 45, 45-50, doi:https://doi.org/10.1016/j.conb.2017.03.005 (2017).

180 Hoang, M. L. et al. Genome-wide quantification of rare somatic mutations in normal human tissues using massively parallel sequencing. 113, 9846-9851 (2016).

181 Lodato, M. A. et al. Aging and neurodegeneration are associated with increased mutations in single human neurons. 359, 555-559 (2018).

182 Luquette, L. J. et al. Ultraspecific somatic SNV and indel detection in single neurons using primary template-directed amplification. 2021.2004.2030.442032, doi:10.1101/2021.04.30.442032 \%J bioRxiv (2021).

183 Abascal, F. et al. Somatic mutation landscapes at single-molecule resolution. Nature 593, 405410, doi:10.1038/s41586-021-03477-4 (2021).

184 Wei, P.-C. et al. Long Neural Genes Harbor Recurrent DNA Break Clusters in Neural Stem/Progenitor Cells. Cell 164, 644-655, doi:https://doi.org/10.1016/j.cell.2015.12.039 (2016). Smith, D. I., Zhu, Y., McAvoy, S. \& Kuhn, R. Common fragile sites, extremely large genes, neural development and cancer. Cancer Lett 232, 48-57, doi:10.1016/j.canlet.2005.06.049 (2006). Gao, G. et al. Common fragile sites (CFS) and extremely large CFS genes are targets for human papillomavirus integrations and chromosome rearrangements in oropharyngeal squamous cell carcinoma. Genes, chromosomes \& cancer 56, 59-74, doi:10.1002/gcc.22415 (2017). 
187 Haas, J. et al. LRP1b shows restricted expression in human tissues and binds to several extracellular ligands, including fibrinogen and apoE - carrying lipoproteins. Atherosclerosis 216, 342-347, doi:10.1016/j.atherosclerosis.2011.02.030 (2011).

188 Hawrylycz, M. J. et al. An anatomically comprehensive atlas of the adult human brain transcriptome. Nature 489, 391 (2012).

189 Beroukhim, R. et al. The landscape of somatic copy-number alteration across human cancers. Nature 463, 899-905, doi:http://www.nature.com/nature/journal/v463/n7283/suppinfo/nature08822_S1.html (2010).

190 Marschang, P. et al. Normal development and fertility of knockout mice lacking the tumor suppressor gene LRP1b suggest functional compensation by LRP1. Mol Cell Biol 24, 3782-3793, doi:10.1128/mcb.24.9.3782-3793.2004 (2004).

191 Shiroshima, T., Oka, C. \& Kawaichi, M. Identification of LRP1B-interacting proteins and inhibition of protein kinase C $\alpha$-phosphorylation of LRP1B by association with PICK1. FEBS letters 583, 43-48 (2009).

192 Cam, J. A. et al. The low density lipoprotein receptor-related protein 1B retains beta-amyloid precursor protein at the cell surface and reduces amyloid-beta peptide production. J Biol Chem 279, 29639-29646, doi:10.1074/jbc.M313893200 (2004).

193 Gan, M., Jiang, P., McLean, P., Kanekiyo, T. \& Bu, G. Low-density lipoprotein receptor-related protein 1 (LRP1) regulates the stability and function of GluA1 $\alpha$-amino-3-hydroxy-5-methyl-4isoxazole propionic acid (AMPA) receptor in neurons. PloS one 9, e113237, doi:10.1371/journal.pone.0113237 (2014).

194 Rabiej, V. K. et al. Low density lipoprotein receptor-related protein 1 mediated endocytosis of $\beta 1$-integrin influences cell adhesion and cell migration. Exp Cell Res 340, 102-115, doi:10.1016/j.yexcr.2015.11.020 (2016).

195 Wu, P., Li, M. S., Yu, D. M. \& Deng, J. B. Reelin, a guidance signal for the regeneration of the entorhino-hippocampal path. Brain research 1208, 1-7, doi:10.1016/j.brainres.2008.02.092 (2008).

196 Stranahan, A. M., Haberman, R. P. \& Gallagher, M. Cognitive Decline Is Associated with Reduced Reelin Expression in the Entorhinal Cortex of Aged Rats. Cerebral Cortex 21, 392-400, doi:10.1093/cercor/bhq106 \%J Cerebral Cortex (2010).

197 Gao, G. et al. Common fragile sites (CFS) and extremely large CFS genes are targets for human papillomavirus integrations and chromosome rearrangements in oropharyngeal squamous cell carcinoma. Genes, Chromosomes and Cancer 56, 59-74 (2017).

198 Escudero-Esparza, A., Kalchishkova, N., Kurbasic, E., Jiang, W. G. \& Blom, A. M. The novel complement inhibitor human CUB and Sushi multiple domains 1 (CSMD1) protein promotes factor I-mediated degradation of $\mathrm{C} 4 \mathrm{~b}$ and $\mathrm{C} 3 \mathrm{~b}$ and inhibits the membrane attack complex assembly. Faseb j 27, 5083-5093, doi:10.1096/fj.13-230706 (2013).

199 Baum, M. L. et al. CUB and Sushi Multiple Domains 1 (CSMD1) opposes the complement cascade in neural tissues. bioRxiv, 2020.2009.2011.291427, doi:10.1101/2020.09.11.291427 (2020).

200 Kraus, D. M., Pfenninger, K. H., Sanford, S. D. \& Holers, V. M. CSMD1 is expressed as a membrane protein on neuronal growth cones that colocalizes with F-actin and alpha-3 integrin. Molecular Immunology 1, 198 (2007).

201 Grubman, A. et al. A single-cell atlas of entorhinal cortex from individuals with Alzheimer's disease reveals cell-type-specific gene expression regulation. Nature neuroscience 22, 2087-2097 (2019).

202 Failla, G. THE AGING PROCESS AND CANCEROGENESIS. Annals of the New York Academy of Sciences 71, 1124-1140, doi:10.1111/j.1749-6632.1958.tb54674.x (1958). 
203 Szilard, L. ON THE NATURE OF THE AGING PROCESS. Proc Natl Acad Sci U S A 45, 30-45, doi:10.1073/pnas.45.1.30 (1959).

204 Wilson, D. M., 3rd, Bohr, V. A. \& McKinnon, P. J. DNA damage, DNA repair, ageing and age-related disease. Mech Ageing Dev 129, 349-352, doi:10.1016/j.mad.2008.02.013 (2008).

205 Coppedè, F. \& Migliore, L. DNA damage and repair in Alzheimer's disease. Curr Alzheimer Res 6, 36-47, doi:10.2174/156720509787313970 (2009).

206 Maynard, S., Fang, E. F., Scheibye-Knudsen, M., Croteau, D. L. \& Bohr, V. A. DNA Damage, DNA Repair, Aging, and Neurodegeneration. Cold Spring Harb Perspect Med 5, a025130, doi:10.1101/cshperspect.a025130 (2015).

207 Hoang, M. L. et al. Genome-wide quantification of rare somatic mutations in normal human tissues using massively parallel sequencing. Proceedings of the National Academy of Sciences 113, 9846-9851 (2016).

208 Xing, D., Tan, L., Chang, C.-H., Li, H. \& Xie, X. S. Accurate SNV detection in single cells by transposon-based whole-genome amplification of complementary strands. Proceedings of the National Academy of Sciences 118, e2013106118, doi:10.1073/pnas.2013106118 (2021).

209 Gómez-Isla, T. et al. Profound loss of layer II entorhinal cortex neurons occurs in very mild Alzheimer's disease. The Journal of neuroscience : the official journal of the Society for Neuroscience 16, 4491-4500, doi:10.1523/jneurosci.16-14-04491.1996 (1996).

210 Chronister, W. D. et al. Neurons with complex karyotypes are rare in aged human neocortex. 26, 825-835. e827 (2019).

211 Wilson, T. E. et al. Large transcription units unify copy number variants and common fragile sites arising under replication stress. 25, 189-200 (2015).

212 Shanbhag, N. M. et al. Early neuronal accumulation of DNA double strand breaks in Alzheimer's disease. Acta Neuropathologica Communications 7, 77, doi:10.1186/s40478-019-0723-5 (2019).

213 Rama, N. et al. Amyloid precursor protein regulates netrin-1-mediated commissural axon outgrowth. The Journal of biological chemistry 287, 30014-30023, doi:10.1074/jbc.M111.324780 (2012).

214 Schartz, N. D. \& Tenner, A. J. The good, the bad, and the opportunities of the complement system in neurodegenerative disease. J Neuroinflammation 17, 354-354, doi:10.1186/s12974020-02024-8 (2020).

215 Schafer, D. P. et al. Microglia sculpt postnatal neural circuits in an activity and complementdependent manner. Neuron 74, 691-705, doi:10.1016/j.neuron.2012.03.026 (2012).

216 Ren, Y. et al. HLA class-I and class-II restricted neoantigen loads predict overall survival in breast cancer. Oncoimmunology 9, 1744947-1744947, doi:10.1080/2162402X.2020.1744947 (2020). 